\title{
c-Kit-Positive Adipose Tissue-Derived Mesenchymal Stem Cells Promote the Growth and Angiogenesis of Breast Cancer
}

\author{
Wenjie Li, ${ }^{1}$ Haiqian $\mathrm{Xu}^{2}{ }^{2}$ and Cheng Qian ${ }^{1}$ \\ ${ }^{1}$ Department of Oncological Surgery, Harbin Medical University Cancer Hospital, Harbin, China \\ ${ }^{2}$ Plastic and Aesthetic Surgery Center, The First Affiliated Hospital of Harbin Medical University, Harbin, China \\ Correspondence should be addressed to Cheng Qian; qiancheng@ems.hrbmu.edu.cn
}

Received 8 November 2016; Revised 28 March 2017; Accepted 4 April 2017; Published 10 May 2017

Academic Editor: Stephen H. Safe

Copyright (c) 2017 Wenjie Li et al. This is an open access article distributed under the Creative Commons Attribution License, which permits unrestricted use, distribution, and reproduction in any medium, provided the original work is properly cited.

\begin{abstract}
Background. Adipose tissue-derived mesenchymal stem cells (ASCs) improve the regenerative ability and retention of fat grafts for breast reconstruction in cancer patients following mastectomy. However, ASCs have also been shown to promote breast cancer cell growth and metastasis. For the safety of ASC application, we aimed to identify specific markers for the subpopulation of ASCs that enhance the growth of breast cancer. Methods. ASCs and bone marrow-derived vascular endothelial progenitor cells (EPCs) were isolated from Balb/c mice. c-Kit-positive (c-Kit ${ }^{+}$) or c-Kit-negative (c-Kit ${ }^{-}$) ASCs were cocultured with $4 \mathrm{~T} 1$ breast cancer cells. Orthotropic murine models of 4T1, EPCs $+4 \mathrm{~T} 1$, and c-Kit ${ }^{+/-}$ASCs $+4 \mathrm{~T} 1 / \mathrm{EPCs}$ were established in Balb/c mice. Results. In coculture, $\mathrm{c}-\mathrm{Kit}^{+}$ASCs enhanced the viability and proliferation of 4T1 cells and stimulated c-Kit expression and interleukin-3 (IL-3) release. In mouse models, c-Kit ${ }^{+} \mathrm{ASC}+4 \mathrm{~T} 1 / \mathrm{EPCs}$ coinjection increased the tumor volume and vessel formation. Moreover, IL3 , stromal cell-derived factor-1, and vascular endothelial growth factor A in the c-Kit ${ }^{+}$ASCs $+4 \mathrm{~T} 1 / \mathrm{EPCs}$ coinjection group were higher than those in the 4T1, EPCs $+4 \mathrm{~T} 1$, and c-Kit ${ }^{-}$ASCs $+4 \mathrm{~T} 1 / \mathrm{EPCs}$ groups. Conclusions. c-Kit ${ }^{+}$ASCs may promote breast cancer growth and angiogenesis by a synergistic effect of c-Kit and IL-3. Our findings suggest that c-Kit ${ }^{+}$subpopulations of ASCs should be eliminated in fat grafts for breast reconstruction of cancer patients following mastectomy.
\end{abstract}

\section{Introduction}

Adipose tissue-derived mesenchymal stem cells (ASCs) with autologous fat improve the regenerative ability and retention of fat grafts and are increasingly being used for breast reconstruction of breast cancer patients following mastectomy [1]. However, increasing evidence has shown that ASCs may promote the growth and metastasis of breast cancer cells [2-5], and several studies have demonstrated that ASCs inhibit the growth of breast cancer $[6,7]$. These contradictory observations may be due to different sources of ASCs, tumor models, and biomarkers for identifying ASCs. To enhance the safety of ASC application in breast reconstruction, it is very important to identify specific biomarkers to distinguish the breast cancer cell growth-promoting ASC subpopulation from other ASC subpopulations that do not enhance the growth and metastasis of breast cancer cells.

c-Kit is a protooncogene located at chromosome 4q12, and its encoding protein is a transmembrane receptor tyrosine kinase $[8,9]$. c-Kit is expressed in many cells of the tumor microenvironment, including mesenchymal, mast, and progenitor cells. In breast cancer, the c-Kit/Kit ligand (KitL) signaling pathway promotes the proliferation, survival, and metastasis of tumor cells [10]. Moreover, the expression level of c-Kit is closely related to triple-negative breast cancer [11]. Recently, it was found that c-Kit ${ }^{+}$ASCs display a higher differentiation potential in comparison to c$\mathrm{Kit}^{-}$ASCs $[12,13]$. These facts suggest that $\mathrm{c}-$ Kit may be a potential biomarker that could distinguish the breast cancer cell growth-promoting ASC subpopulation from other ASC subpopulations.

The growth and metastasis of tumor cells is dependent on vessel formation in the tumor mass [14]. It has been shown that tumor cells recruit bone marrow-derived vascular endothelial progenitor cells (BM-EPCs) by increasing the expression of hypoxia-inducible factor- $1 \alpha$ (HIF- $1 \alpha$ ) and vascular endothelial growth factor (VEGF), both of which play 
an important role in angiogenesis $[15,16]$. The interaction of EPCs and tumor cells can enhance angiogenesis, which plays a crucial role in the growth and metastasis of tumor cells [17, 18]. ASCs have been demonstrated to promote angiogenesis by secreting growth factors within a variety of tumor types [19-22]. However, since the tumor microenvironment is very complex, whether ASCs differentiate into endothelial-like cells or recruit endothelial cells for vessel formation during tumor angiogenesis remains to be determined.

To explore the role and mechanism of $\mathrm{c}-\mathrm{Kit}^{+}$ASCs in breast cancer progression, in this study, we established a coculture model of ASCs and breast cancer cells. Furthermore, we analyzed the impact of $\mathrm{c}-\mathrm{Kit}^{+} \mathrm{ASCs}$ on tumor angiogenesis using breast cancer mouse models.

\section{Materials and Methods}

2.1. Cell Culture. 4T1 breast cancer cells were purchased from the American Type Culture Collection (Manassas, VA, USA) and cultured in RIPM-1640 medium (Lonza, Walkersville, MD, USA) supplemented with $10 \%$ fetal bovine serum (FBS) (Gibco, Grand Island, NY, USA), 2 mM glutamine, $100 \mathrm{U} / \mathrm{mL}$ penicillin, and $100 \mu \mathrm{g} / \mathrm{mL}$ streptomycin.

2.2. Animals. Four-week-old female nude mice (Balb/c) were obtained from the SLAC Laboratory Animal Corporation (Shanghai, China) and were housed in a specific pathogenfree room. The Animal Committee of Harbin Medical University approved all the experimental protocols and animal handling procedures. All experimental procedures and postoperative animal care were conducted in accordance with the National Institute of Health's Guidelines for the Care and Use of Laboratory Animals.

2.3. Preparation of $\mathrm{c}$-Kit ${ }^{+}$ASCs. Six-week-old Balb/c female mice were sacrificed by cervical dislocation, and inguinal fat tissues were dissected. After mincing the tissues into 2$3 \mathrm{~mm}$ pieces, they were digested with $200 \mathrm{U} / \mathrm{mL}$ collagenase II (Sigma, St. Louis, MO, USA) for $30 \mathrm{~min}$, followed by centrifugation at $1200 \mathrm{rpm}$ for $10 \mathrm{~min}$. The pellets were sequentially filtered through 200 mesh filters and centrifuged at $12,000 \mathrm{rpm}$ for $10 \mathrm{~min}$. The pelleted cells were washed twice with phosphate-buffered saline (PBS) and resuspended in Dulbecco's modified Eagle medium (DMEM; Lonza) containing $10 \%$ FBS. The cells were grown at $37^{\circ} \mathrm{C}$ in a humidified atmosphere containing $5 \% \mathrm{CO}_{2}$, and the medium was changed daily for 2-3 days. After 3 weeks of culture, c-Kit ${ }^{+} / \mathrm{CD}^{+} 0^{+}$cells were isolated by magnetic bead separation and further purified by fluorescence-activated cell sorting. The adipogenic differentiation potential of ASCs was routinely induced for 2 weeks using medium supplementation (1:1 DMEM/Hams F-12 containing 3\% fetal calf serum, $100 \mathrm{nM}$ insulin, $1 \mu \mathrm{M}$ dexamethasone, and $0.25 \mathrm{mM}$ 3-isobutyl-1-methylxanthine) and determined using oil red $\mathrm{O}$ staining, following standard protocols.

2.4. Preparation of BM-EPCs. Bone marrow cells were isolated from the femurs of Balb/c female mice and diluted in Histopaque-1083 (Sigma) (7:4), immediately followed by centrifugation at $2400 \mathrm{rpm}$ for $25 \mathrm{~min}$ at room temperature. The layer of bone marrow cells at the opaque interface was transferred to a tube containing PBS and centrifuged at $1500 \mathrm{rpm}$ for $10 \mathrm{~min}$ at $4^{\circ} \mathrm{C}$. EPCs from the mononuclear cells were isolated with CD34 and VEGFR2 magnetic bead separation (Miltenyi Biotech Inc., Auburn, CA, USA) and cultured in endothelial cell growth medium-2 (EGM-2; Lonza) at $37^{\circ} \mathrm{C}$ and $5 \% \mathrm{CO}_{2}$ in a humidified incubator. Medium was changed daily for 2-3 days.

2.5. Immunofluorescence. The adherent cells were trypsinized and plated on EZ slides (Millipore, Billerica, MA, USA) for immunofluorescence assays. The cells were labeled with monoclonal rat anti-CD90 antibody (Abcam, Cambridge, MA, USA), followed by donkey anti-rat secondary antibody conjugated with Alexa Fluor 488 (Thermo Scientific, Waltham, MA, USA). For c-Kit staining, cells were incubated with polyclonal rabbit anti-c-Kit (Abcam) antibody, followed by incubation with goat anti-rabbit secondary antibody conjugated with Alexa Fluor 647 (Abcam). After incubation with $4^{\prime}, 6$-diamidino-2-phenylindole (Thermo Scientific) for $1 \mathrm{~min}$, the cells were observed under a fluorescence microscope (Olympus, Tokyo, Japan). The percentages of $\mathrm{c}-\mathrm{Kit}^{+}$ and $\mathrm{CD}^{+} 0^{+}$cells during each isolation were analyzed using Image J software.

2.6. Direct Coculture of ASCs with $4 \mathrm{T1}$ Cells. c-Kit ${ }^{+}$or c$\mathrm{Kit}^{-}$ASCs were cocultured with $4 \mathrm{~T} 1$ cells at a ratio of $1: 1$. The cells were plated on gelatin-coated (1\% in PBS) 24 -well plates and cultured in DMEM at a density of $50,000 / \mathrm{cm}^{2}$. As controls, 4T1 cells or ASCs alone were cultured under the same conditions. The cells were incubated for $1-5$ days at $37^{\circ} \mathrm{C}$ with humidified $5 \% \mathrm{CO}_{2}$.

2.7. Indirect Coculture of ASCs with 4T1 Cells. In a 24-well Transwell culture plate (Corning, NY, USA), $3 \times 10^{4} 4 \mathrm{~T} 1$ cells were plated in the bottom chamber and $3 \times 10^{4}$ ASCs were plated in the upper chamber in DMEM. The chambers were incubated for $1-5$ days in a $37^{\circ} \mathrm{C}$ incubator with humidified $5 \% \mathrm{CO}_{2}$.

2.8. Tube Formation Assay. Matrigel (BD, Franklin Lakes, NJ, USA) was added to a 96-well plate, $50 \mu \mathrm{L}$ per well. After incubation at $37^{\circ} \mathrm{C}$ with $5 \% \mathrm{CO}_{2}$ for $1 \mathrm{~h}$, ASCs or EPCs $\left(10^{4}\right)$ in $100 \mu \mathrm{L}$ of culture medium were added. The cells were incubated for $18 \mathrm{~h}$, and the area of tube formation was recorded using imaging software (Olympus, Tokyo, Japan).

2.9. Cell Viability Assay. Approximately $3 \times 10^{3} 4 \mathrm{~T} 1$ cells were cultured in culture supernatant from ASCs in 96-well plates. After 1-5 days, $10 \mu \mathrm{L}$ of cell counting kit-8 (CCK-8) solution was added per well, and the cells were further incubated at $37^{\circ} \mathrm{C}$ with $5 \% \mathrm{CO}_{2}$ for $3 \mathrm{~h}$. Then, the absorbance at $450 \mathrm{~nm}$ was recorded using a microplate reader.

2.10. Cell Proliferation. DNA quantification was performed to assess cell proliferation using the Quant-iT PicoGreen dsDNA reagent and kit (Invitrogen, Carlsbad, CA, USA). After culturing for 1-5 days, the 4T1 cells in the direct 
coculture model were washed two times with PBS, and $200 \mu \mathrm{L}$ of $0.2 \%(\mathrm{v} / \mathrm{v})$ Triton X-100/5 $\mathrm{mM} \mathrm{MgCl}_{2}$ was added to the cells. Following digestion, the samples were centrifuged at $12,000 \mathrm{rpm}$ for $10 \mathrm{~min}$ at $4^{\circ} \mathrm{C}$. The supernatant $(100 \mu \mathrm{L})$ was transferred to a 96-well plate, and $100 \mu \mathrm{L}$ of PicoGreen fluorescence reagent (1:200 in Tris-EDTA buffer) was added. Fluorescence was measured in a microplate reader (Nanodrop 3300, Thermo Scientific), and values were calculated using known DNA standards.

2.11. RNA Extraction and Quantitative Real-Time Polymerase Chain Reaction ( $q P C R)$. Total RNA was extracted using RNeasy Mini Kits (QIAGEN, Düsseldorf, Germany), according to the manufacturer's protocol. Total RNA $(1 \mu \mathrm{g})$ was reverse-transcribed into cDNA using a QuantiTect Reverse Transcription Kit (QIAGEN). The primer sequences used were as follows: mouse c-Kit forward, $5^{\prime}$-CTGACGTGCATTGATCCCGA-3', reverse, $5^{\prime}$-CTCGTGAGGCCATTGCTGTT-3'; GAPDH forward, $5^{\prime}$-AGGTCGGTGTGAACGGATTTG-3' , reverse, $5^{\prime}$-GGGGTCGTTGATGGCAACA-3' . The qPCR was performed on a CFX900 thermal cycler (BioRad, Hercules, CA, USA) using THUNDERBIRD SYBR PCR Mix (TOYOBO, Osaka, Japan), according to the manufacturer's protocol. GAPDH was used as an internal control. Amplification parameters were as follows: one cycle of $50^{\circ} \mathrm{C}$ for $2 \mathrm{~min}, 95^{\circ} \mathrm{C}$ for $3 \mathrm{~min}$, followed by 40 cycles of $95^{\circ} \mathrm{C}$ for $10 \mathrm{~s}$ and $60^{\circ} \mathrm{C}$ for $30 \mathrm{~s}$. Relative expression was determined using the comparative threshold cycle method $\left(2^{-\Delta \Delta \mathrm{Ct}}\right)$.

2.12. Western Blot Analysis. Total proteins were extracted using a total protein extraction kit (Vazyme Biotech, Nanjing, China), and concentration was measured using a bicinchoninic acid protein assay kit (Beyotime Biotechnology, Shanghai, China). A total of $20 \mu \mathrm{g}$ of protein was separated by $7.5 \%$ sodium dodecyl sulfate-polyacrylamide gel electrophoresis and transferred onto a polyvinylidene difluoride membrane. The membrane was incubated in blocking buffer containing 5\% nonfat dry milk in Tris-buffered saline and Tween $20(10 \mathrm{mM}$ Tris- $\mathrm{HCl}, \mathrm{pH} 8.0,100 \mathrm{mM}$ $\mathrm{NaCl}$, and $0.05 \%$ Tween) for $1 \mathrm{~h}$ at room temperature. After incubating the membrane with primary antibody (rabbit anti-c-Kit antibody diluted at $1: 3000$ ) overnight at $4^{\circ} \mathrm{C}$ and horseradish peroxidase- (HRP-) conjugated goat antirabbit antibody (1:4000, Abcam) for $2 \mathrm{~h}$ at room temperature, protein-antibody complexes were visualized with an Enhanced Chemiluminescence Western Blotting Detection Kit (Beyotime Biotechnology, Shanghai, China) and analysis system (Bio-Rad). $\beta$-Actin was detected by the same method as a loading control.

2.13. Enzyme-Linked Immunosorbent Assay (ELISA). Cell culture supernatant was collected after culturing for 1, 3, and 5 days by centrifugation for $20 \mathrm{~min}$ at $1000 \mathrm{rpm}$. Primary tumor tissues were rinsed in ice-cold PBS to remove excess blood and weighed. The tissues were minced into small pieces and crushed with liquid nitrogen in a mortar. The resulting suspension was sonicated and centrifuged for $5 \mathrm{~min}$ at $5000 \mathrm{rpm}$. The supernatant was immediately subjected to cytokine and chemokine detection with a commercially available ELISA kit (Cloud-Clone Corp., Houston, TX, USA), according to the manufacturer's protocols.

2.14. Animal Model. Subcutaneous orthotopic injection in 4-week-old female nude mice $(\mathrm{BALB} / \mathrm{c})$ was performed under general anesthesia $(1.2 \%$ Avertin, $0.1 \mathrm{~mL} / 10 \mathrm{~g})$. The cells, including $10^{5} 4 \mathrm{~T} 1$ cells, $10^{5}$ ASCs, and $10^{4}$ EPCs, were resuspended in $200 \mu \mathrm{L}$ of PBS/Matrigel and injected into the mammary fat pads of female nude mice alone or EPCs + $4 \mathrm{~T} 1$ or ASCs $+4 \mathrm{~T} 1 / \mathrm{EPC}$ coinjections. In every group $(n=$ 5 ), the tumor size was measured twice/week, and the tumor volume was calculated according to the following formula: tumor volume $=0.5 \times\left(D_{\max } \times D_{\min }{ }^{2}\right)$. Three weeks after injection, the mice were sacrificed and the primary tumors were removed for further evaluation.

2.15. Immunohistochemistry. After tumor removal, the fresh tumors were immediately embedded in optimum cutting temperature compound (Sakura, Zoeterwoude, Netherlands) and sectioned ( $5 \mathrm{~mm})$, followed by staining with hematoxylin and eosin (H\&E), CD31 antibody, and oil red O. Briefly, sections mounted on slides were dehydrated in ethanol, rinsed in PBS containing Tween 20 (PBST), and incubated with $0.3 \%$ hydrogen peroxide for $15 \mathrm{~min}$. After washing with PBST, sections were blocked by incubation in 3\% bovine serum albumin for $30 \mathrm{~min}$, followed by overnight incubation with primary antibody (rabbit anti-CD31 diluted 1:50; Abcam). Slides were washed with PBST followed by a $1 \mathrm{~h}$ incubation with HRP-conjugated goat anti-rabbit secondary antibody (1:4000, Abcam), rinsed in PBST, and exposed to $3,3^{\prime}$-diaminobenzidine (Solarbio, Beijing, China). Then, counterstaining was performed with hematoxylin (Solarbio, Beijing, China). For H\&E staining, sections were stained in hematoxylin for $3 \mathrm{~min}$, washed in water, and then exposed for $5 \mathrm{~min}$ to eosin (Solarbio). The immunostaining results were analyzed using imaging software (Olympus, Tokyo, Japan).

2.16. Statistical Analysis. All experiments were performed in triplicate. All data were statistically analyzed using SPSS version 13.0, and graphs were made using GraphPad Prism version 5.0 software. One-way analysis of variance and Newman-Keuls post hoc tests were used to compare variance between groups. A $p$ value $\leq 0.05$ was considered as a significant difference. Differences were considered highly significant when $p \leq 0.01$.

\section{Results}

3.1. Isolation and Characterization of ASCs and EPCs from Mice. To investigate whether $\mathrm{c}^{-\mathrm{Kit}^{+}}$ASCs promote the growth of breast cancer cells, we isolated ASCs from mouse inguinal adipose tissues. The isolated ASCs appeared as a spindle shape, and oil red $\mathrm{O}$ staining showed that adipogenic differentiation of sorted ASCs contained lipid drops inside their cytoplasms, a feature of mature adipocytes (Figure 1(a)). The cells obtained from mouse adipose tissues were mostly $\mathrm{CD}^{+}$cells and included a c-Kit ${ }^{+}$subpopulation (Figures 1(b), 1(c), and 1(d)). Nevertheless, there were very few cells that were positive for the endothelial progenitor cell 

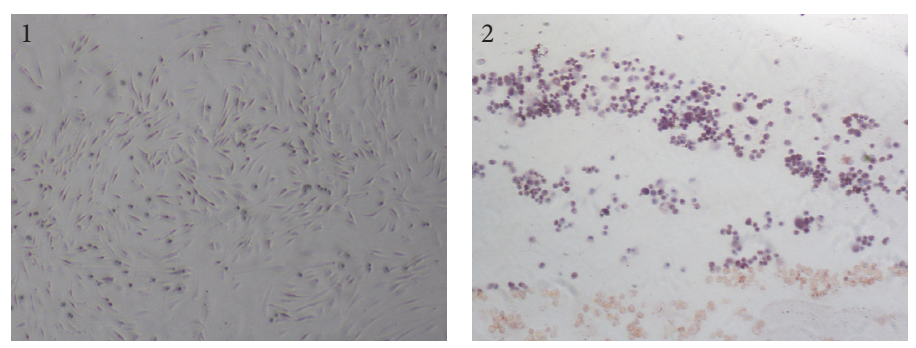

(a)
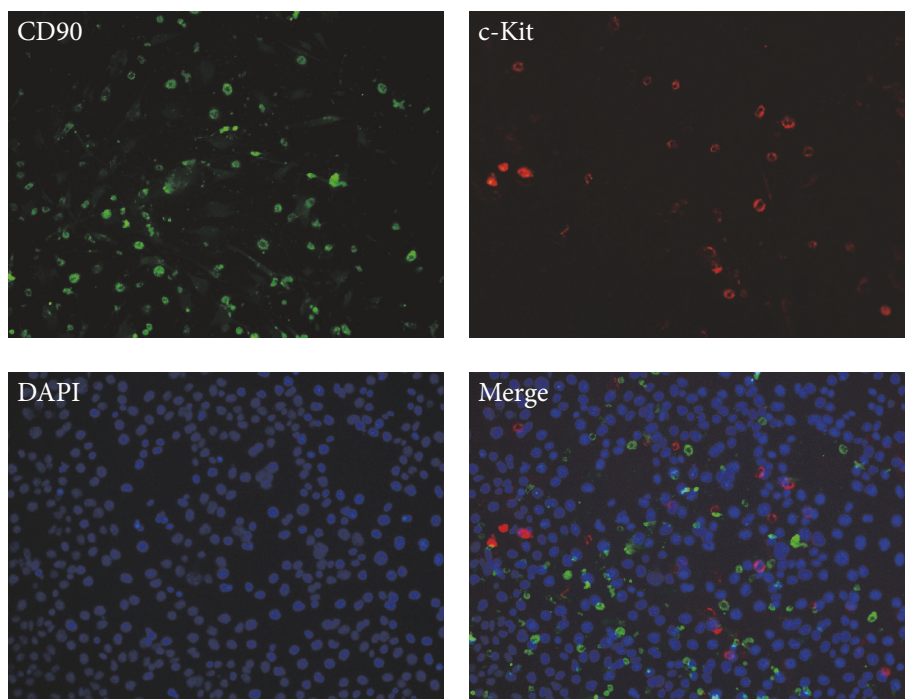

(b)

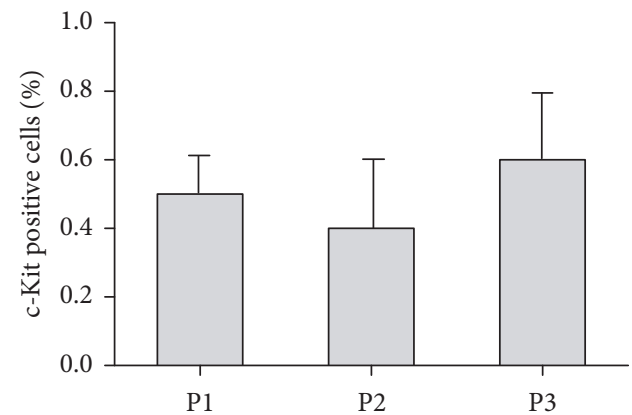

(c)
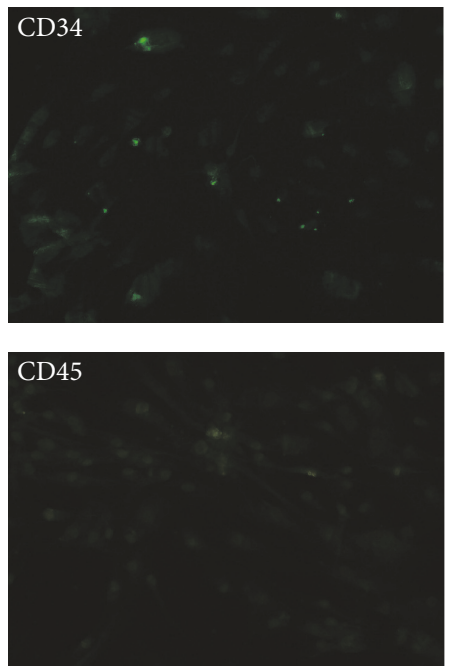

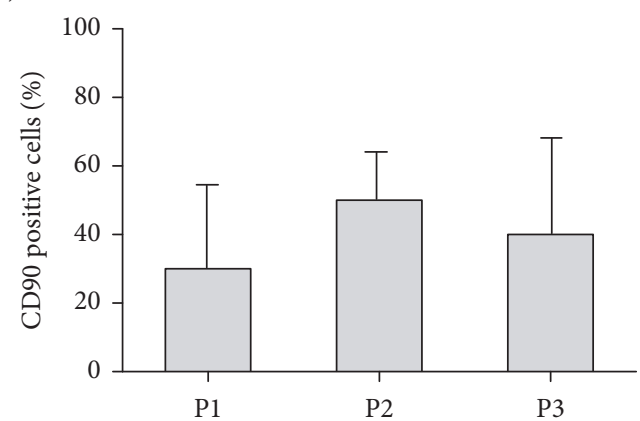

(d)
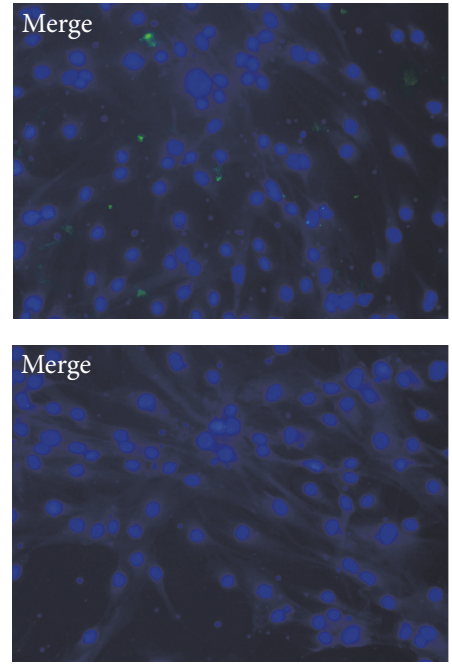

(e)

Figure 1: Continued. 

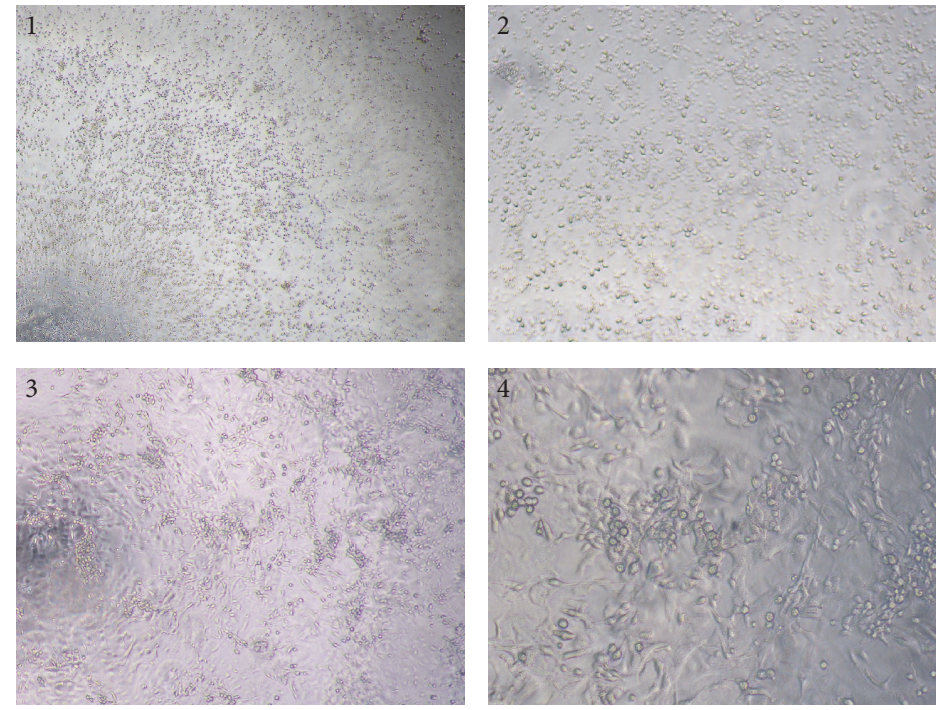

(f)

FIGURE 1: The characterization of isolated ASCs and EPCs. ASCs were isolated from inguinal adipose tissue of Balb/c female mice and cultured in DMEM. The cells were placed on EZ slides for detection of biomarker expression using immunofluorescence. BM-EPCs were isolated from the femurs of Balb/c female mice and cultured in EGM-2. A total of $1 \times 10^{3}$ EPCs were plated on methylcellulose containing EGM-2 medium for 8-10 days, and colony formation units were defined as cluster-like collections of cells. (a) The morphology and differentiation potential of ASCs. ASCs appeared as a spindle shape, and adipogenic differentiation was confirmed by oil red O staining. (b) Isolated ASCs were stained for c-Kit and CD90 expression. ((c)-(d)) The percentages of $\mathrm{c}-\mathrm{Kit}^{+}$and $\mathrm{CD} 90^{+}$cells during each isolation. (e) Isolated ASCs were stained for CD34 and CD45 expression. (f) The morphology and colony formation assay in EPCs. EPCs cultured for 7-14 days demonstrated a cobblestone appearance on collagen-coated plates and cell-cluster formation on methylcellulose. (a)1, (a)2, (f)1, and (f)3: 40× magnification; (b) and (f)2: $100 \times$ magnification; (e) and (f) 4: 200× magnification. ASCs: adipose-derived mesenchymal stem cells; EPCs: endothelial progenitor cells.

marker CD34, and no $\mathrm{CD}_{4} 5^{+}$subpopulation was found by immunofluorescence staining (Figure $1(\mathrm{e})$ ). These results indicated that the isolated and expanded cells including c$\mathrm{Kit}^{+} / \mathrm{CD} 90^{+}$ASCs were not contaminated with endothelial or hematopoietic cells.

To assess whether the interaction of ASCs and EPCs promotes breast cancer angiogenesis, we isolated BM-EPCs from mice. The isolated mononuclear cells appeared as round-shaped cells that attached on plates at days 3-5. At days 7-14, the cells demonstrated a cobblestone appearance on gelatin-coated plates, which is a characteristic of EPCs. In methylcellulose media, EPCs demonstrated cellcluster formation consistent with the ability to form colonies (Figure 1(f)). These results indicated a successful isolation of EPCs from mouse bone marrow.

3.2. $\mathrm{c}$-Kit ${ }^{+}$ASCs Promote the Viability and Proliferation of Breast Cancer Cells. To test the effects of $\mathrm{c}-\mathrm{Kit}^{+}$ASCs on the viability and proliferation of breast cancer cells, we cocultured ASCs with $4 \mathrm{~T} 1$ cells. With a direct coculture model, we found that the mRNA expression of c-Kit was significantly higher in the coculture group than in the $\mathrm{c}-\mathrm{Kit}^{+}$ASCs alone group $(p<0.001$, Figure 2(a)). Western blot analysis showed no detectable c-Kit protein in the 4T1 cells alone group, but there was a higher c-Kit protein level in the coculture group than in the ${\mathrm{c}-\mathrm{Kit}^{+}}^{+}$ASCs alone group (Figure 2(b)). However, we did not observe c-Kit expression in the $\mathrm{c}^{-\mathrm{Kit}^{-}}$ASCs alone or coculture group, which suggests that $4 \mathrm{~T} 1$ cancer cells may increase c-Kit expression in c-Kit ${ }^{+}$ASCs (Figure 2(b)).
To assess the effect of ASCs on 4T1 cell proliferation, we performed an indirect coculture of ASCs with $4 \mathrm{~T} 1$ cells and determined the viability of $4 \mathrm{~T} 1$ cells for 5 days. After cell culture for 3 days, the viability of 4T1 cells was significantly enhanced in the coculture with $\mathrm{c}-\mathrm{Kit}^{+}$ASCs, compared to the $4 \mathrm{~T} 1$ cell culture alone group $(p<0.05$, Figure $2(\mathrm{c}))$. The cell proliferation assay using a Quant-iT PicoGreen kit found that the proliferation of $4 \mathrm{T1}$ cells was significantly increased in the coculture with c- $\mathrm{Kit}^{+} \mathrm{ASCs}$, compared to the culture of $4 \mathrm{~T} 1$ cells alone for $4-5$ days $(p<0.01$, Figure $2(\mathrm{~d})$ ). These results suggest that $\mathrm{c}-\mathrm{Kit}^{+}$ASCs promote the viability and proliferation of breast cancer cells.

3.3. Effect of c-Kit ${ }^{+}$ASCs on Primary 4 T1 Tumor Growth In Vivo. ASCs affect tissue regeneration and homeostasis, and c-Kit ${ }^{+}$ASCs have a higher differentiation potential compared to other subpopulations of mesenchymal stem cells in adipose tissue $[12,13]$. In addition, tumor growth depends on vessel formation. Nevertheless, our Matrigel assay showed that both $\mathrm{c}-\mathrm{Kit}^{+}$and $\mathrm{c}-\mathrm{Kit}^{-}$ASCs showed no tube formation ability in comparison to EPCs (Figure 2(e)). To explore whether ${\mathrm{c}-\mathrm{Kit}^{+}}^{+}$ASCs promote breast cancer growth in vivo, we performed subcutaneous coinjection of $4 \mathrm{~T} 1$ cells with ASCs in combination with EPCs into nude mice and observed the effect of $\mathrm{c}-\mathrm{Kit}^{+}$ASCs on 4T1 tumor growth. We found that injection of $4 \mathrm{~T} 1$ cells alone formed a palpable tumor (Figure 3(a)). In the coinjection groups, the tumor growth was markedly stimulated in comparison to the injection of 4T1 cells alone $(p<0.01$, Figures $3(\mathrm{a})$ and $3(\mathrm{~b}))$. 


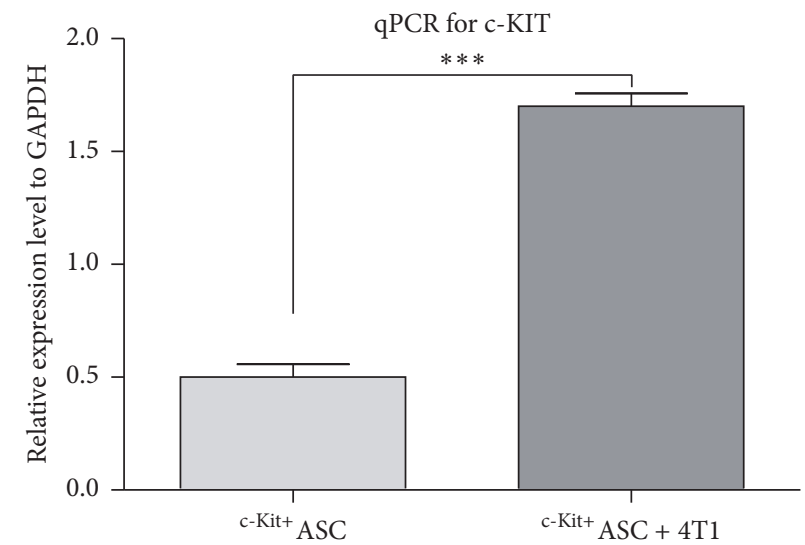

(a)

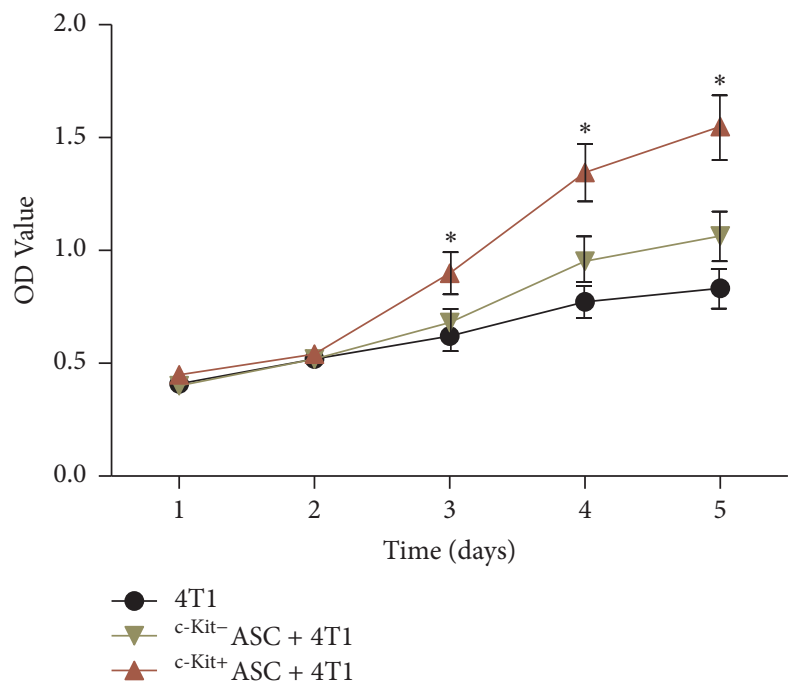

(c)
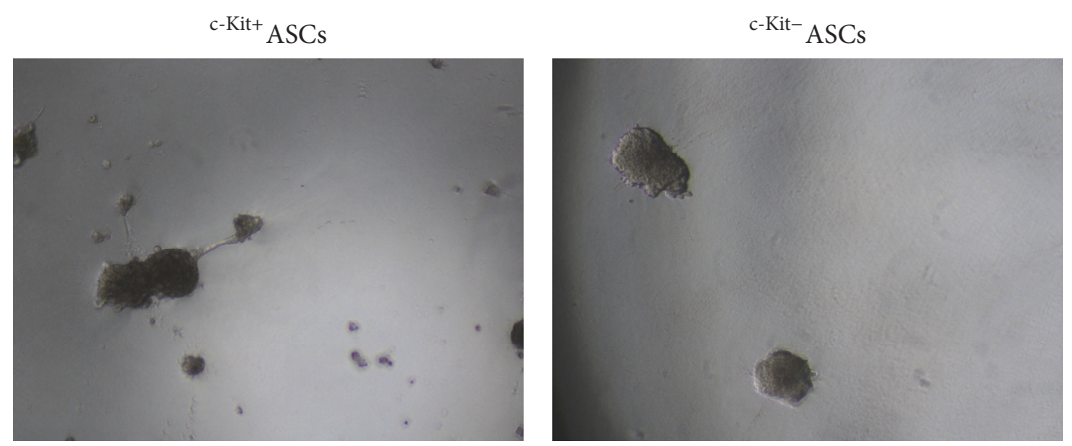

(e)

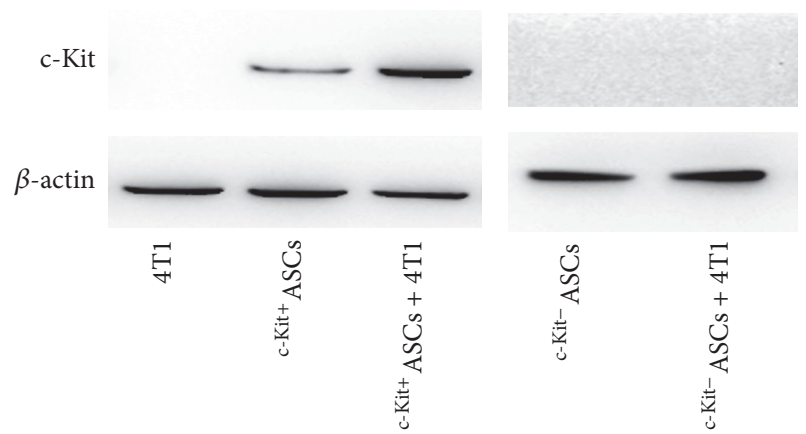

(b)
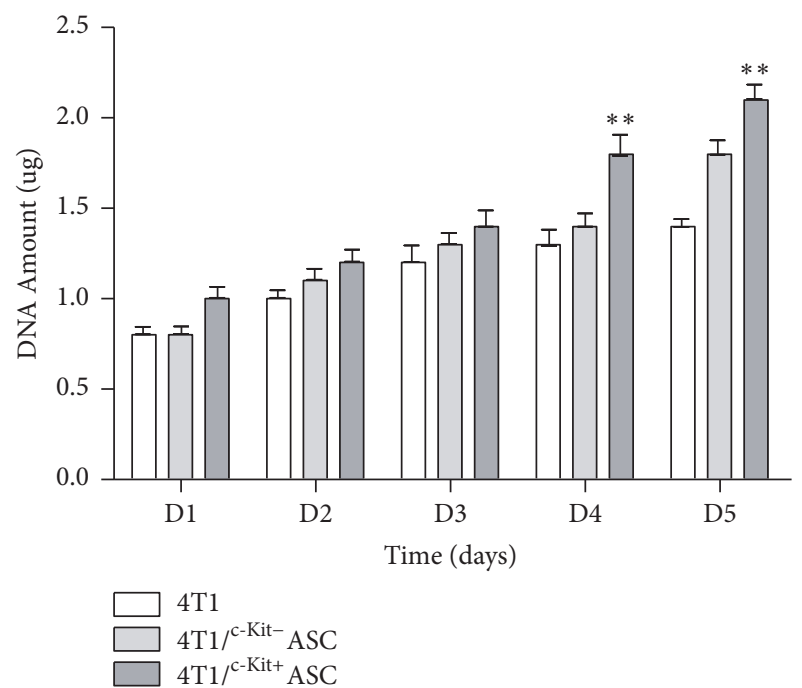

(d)

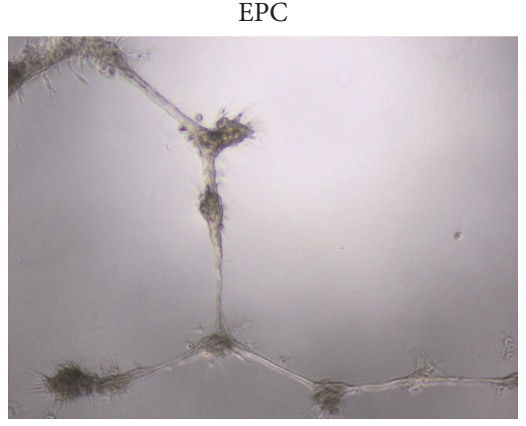

Figure 2: Effects of c-Kit expression of ASCs on $4 \mathrm{~T} 1$ breast cancer cells. ASCs and 4T1 cells were cocultured in a ratio of $1: 1$. After culturing, RNA and protein were extracted to detect the c-Kit mRNA and protein expression in different culture models. After 1-5 days, the viability and proliferation of $4 \mathrm{~T} 1$ cells were detected using a CCK- 8 assay and DNA quantification, respectively, in indirect coculture experiments. For the tube formation assay, $10^{4}$ ASCs and $10^{4}$ EPCs were plated on Matrigel, respectively, and incubated for $18 \mathrm{~h}$, and then the area of tube formation was observed. (a) The mRNA expression of c-Kit was higher in the c-Kit ${ }^{+}$ASCs $+4 \mathrm{~T} 1$ direct coculture group than in the single culture groups using qPCR, and the expression of c-Kit mRNA was not detected in the 4T1 cells. The qPCR results were normalized against GAPDH. (b) The level of c-Kit protein expression in the c-Kit ${ }^{+}$ASCs $+4 \mathrm{~T} 1$ direct coculture group was higher than that in the single culture groups by western blot analysis. But no c-Kit protein expression was detected in the c-Kit ${ }^{-}$ASCs $+4 \mathrm{~T} 1$ group. Anti- $\beta$-actin antibody served as a control. ((c)-(d)) The viability and proliferation of $4 \mathrm{~T} 1$ cells were enhanced by c-Kit ${ }^{+}$ASCs, compared to the other culture groups. (e) The $\mathrm{c}-\mathrm{Kit}^{+} / \mathrm{c}-\mathrm{Kit}^{-}$ASCs had no potential of tube formation compared with EPCs. ${ }^{*} p<0.05 ;{ }^{* *} p<0.01$; ${ }^{* * *} p<0.001$. (e): 200x magnification. 


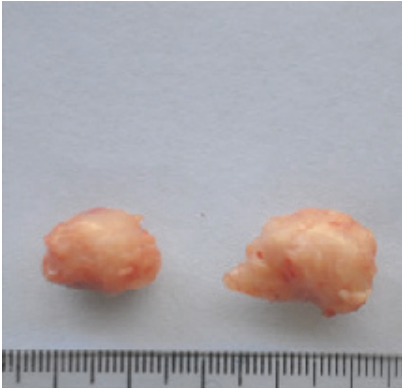

$4 \mathrm{~T} 1$

$\mathrm{EPC}+4 \mathrm{~T} 1$

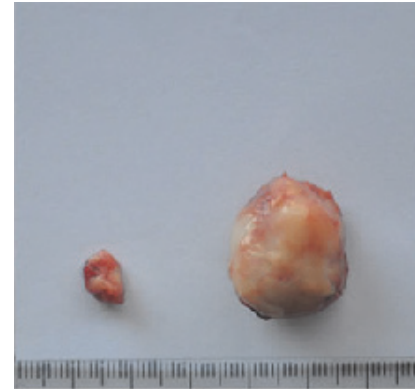

${ }^{c-K i t-}$ ASC ${ }^{c-K i t-}$ ASC + 4T1/EPC

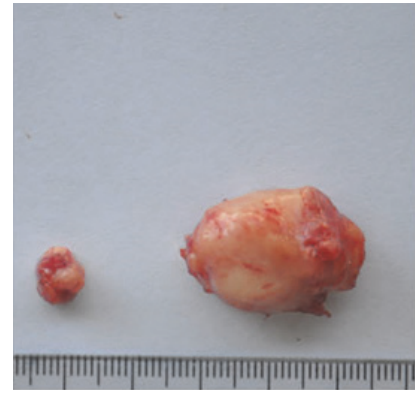

${ }^{\mathrm{c}-\mathrm{Kit}+}$ ASC $\quad{ }^{\mathrm{c}-\mathrm{Kit}+} \mathrm{ASC}+4 \mathrm{~T} 1 / \mathrm{EPC}$

(a)

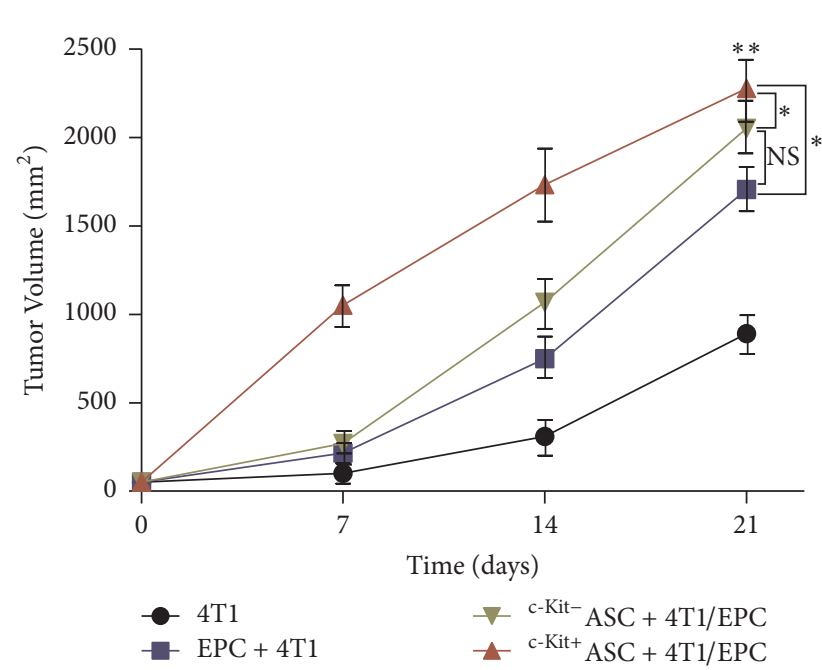

(b)

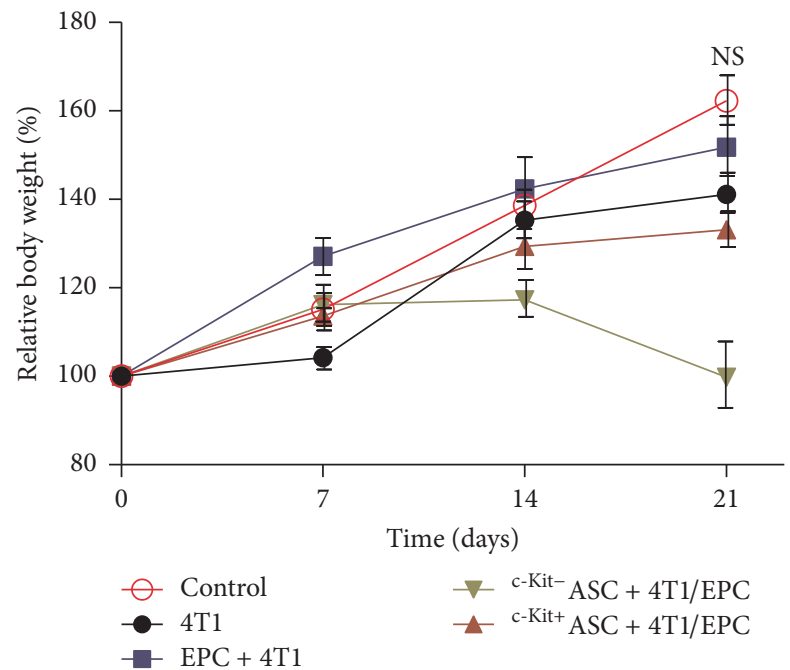

(c)

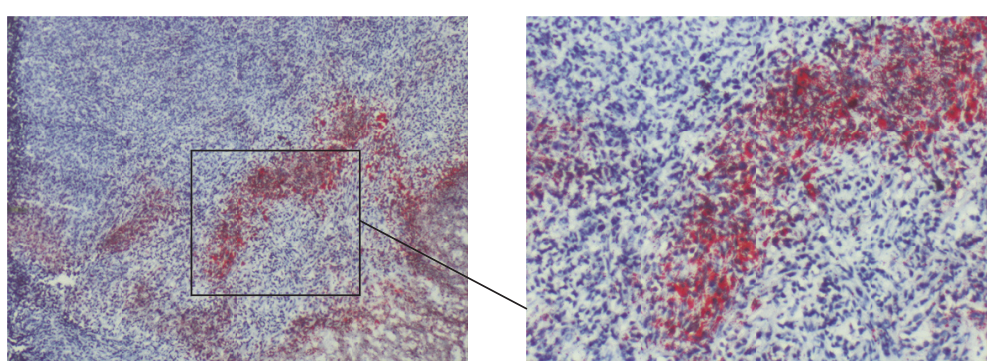

(d)
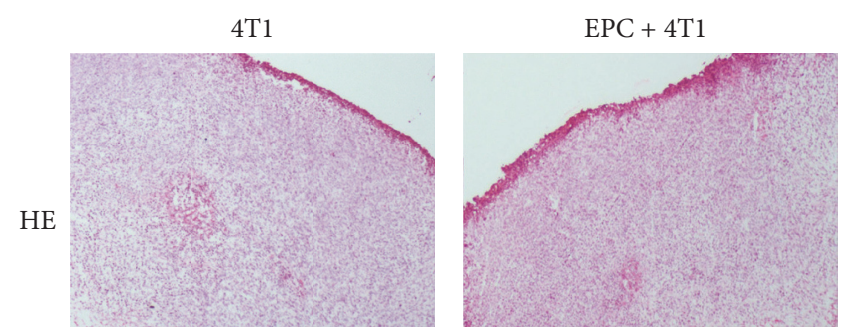

c-Kit- ASCs + 4T1/EPC

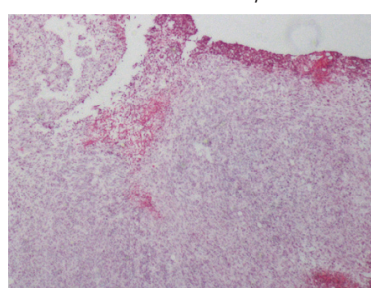

${ }^{\mathrm{c}-\mathrm{Kit}+} \mathrm{ASCs}+4 \mathrm{~T} 1 / \mathrm{EPC}$
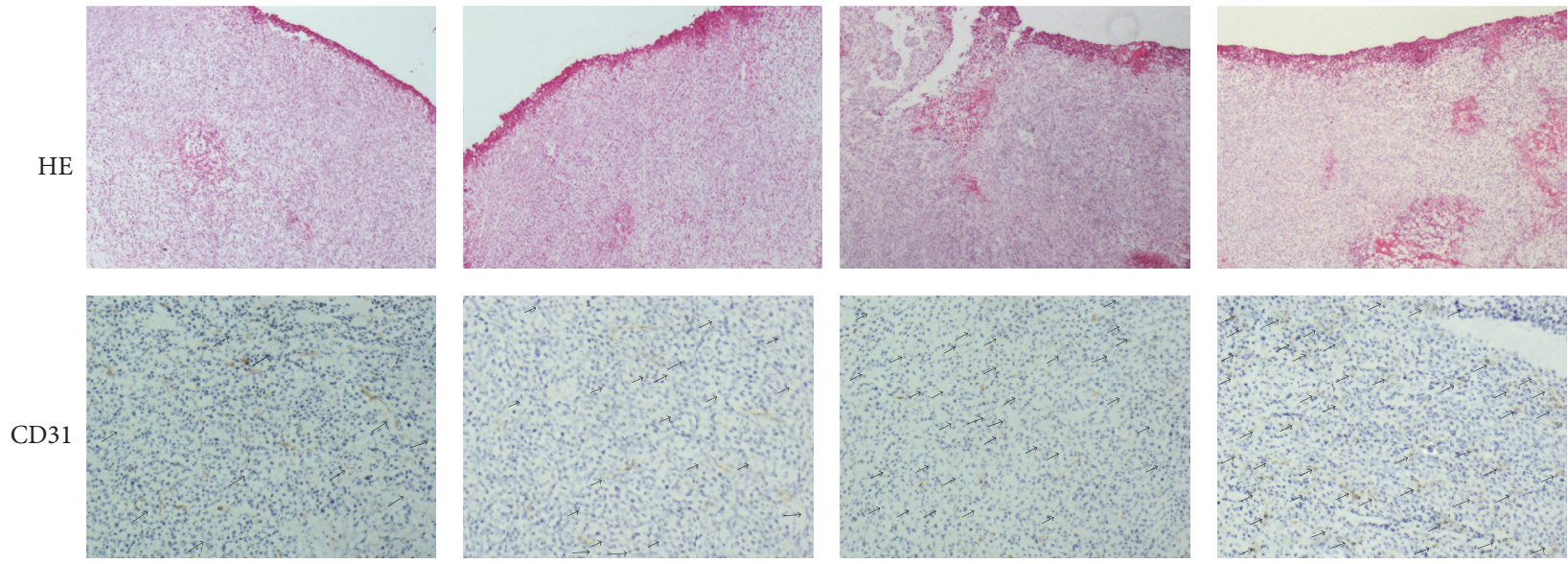

(e)

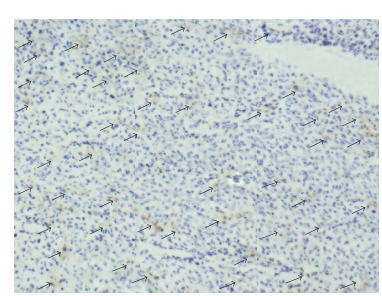

Figure 3: Continued. 


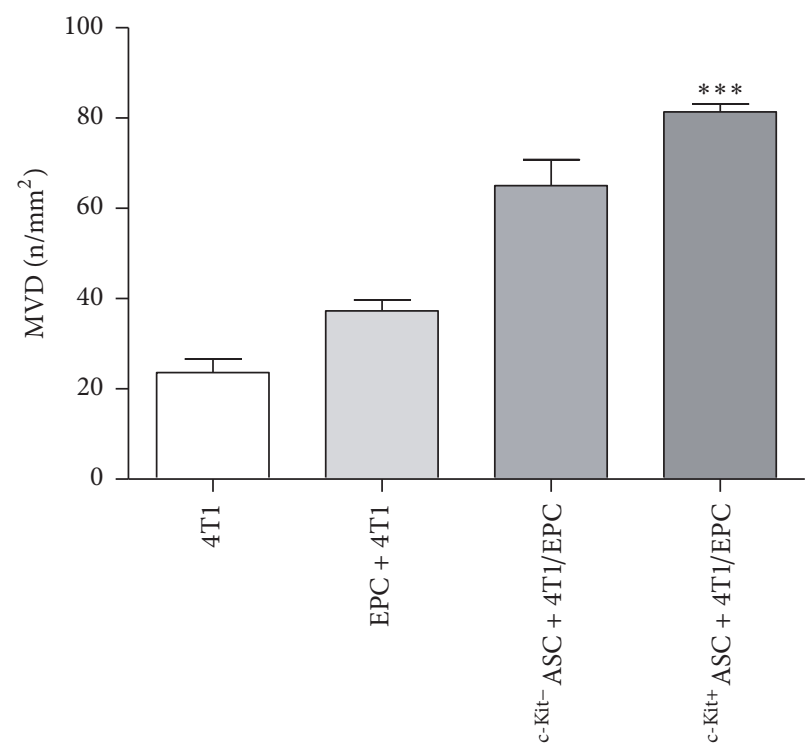

(f)

FIGURE 3: The effect of c-Kit ${ }^{+}$ASCs on tumorigenesis and angiogenesis of $4 \mathrm{~T} 1$ breast cancer cells in vivo. c-Kit ${ }^{+}$ASCs $\left(10^{5}\right)$ with $4 \mathrm{~T} 1$ cells $\left(10^{5}\right)$ and EPCs $\left(10^{4}\right)$ were suspended in $200 \mu \mathrm{L}$ of PBS/Matrigel and injected onto mammary fat pads of female nude mice as follows: injection alone or EPCs + 4T1 or ASCs + 4T1/EPCs coinjection. Tumor growth and vessel formation were detected. ((a)-(b)) The primary tumor volume was significantly increased in the c-Kit ${ }^{+}$ASCs coinjection group, compared with the other injection groups. (c) The weight of the nude mouse increased, and no significant differences between groups, except for a decrease in the c-Kit ${ }^{-}$ASC coinjection group at 14 days after injection, were observed. (d) Mature adipose formation in the tumor was confirmed by oil red $\mathrm{O}$ staining in the ASC coinjection groups. (e) H\&E staining and CD31 immunostaining showed broad vessel formation in the tumors, as indicated by the arrows. (f) The microvascular density was higher in the tumors containing c-Kit ${ }^{+}$ASCs than in the other injection groups. ${ }^{*} p<0.05 ;{ }^{* *} p<0.01{ }^{* * *} p<0.001$. (d) (left) and (e): 40x magnification; (d) (right): 100x magnification. CD31: platelet endothelial cell adhesion molecule-1. MVD: microvascular density.

Furthermore, the tumor volume was significantly increased in the $\mathrm{c}-\mathrm{Kit}^{+} \mathrm{ASCs}+4 \mathrm{~T} 1 / \mathrm{EPCs}$ group, compared with the c-Kit ${ }^{-} \mathrm{ASCs}+4 \mathrm{~T} 1 / \mathrm{EPCs}$ group and the EPCs/4T1 group $\left(2275 \mathrm{~mm}^{2}\right.$ versus $2052 \mathrm{~mm}^{2}$ and $2275 \mathrm{~mm}^{2}$ versus $1705 \mathrm{~mm}^{2}$, respectively; $p<0.05$, Figures 3(a) and 3(b)). Although the tumor volume in the c-Kit ${ }^{-} \mathrm{ASCs}+4 \mathrm{~T} 1 / \mathrm{EPC}$ group was larger than that of the EPCs/4T1 group up to 21 days after injection (2052 $\mathrm{mm}^{2}$ versus $1705 \mathrm{~mm}^{2}$, Figures 3(a) and 3(b)), the difference was not significant $(p>0.05$, Figure 3(b)). In addition, 14 days after injection, the weights of the nude mice significantly declined by $0.24 \%$ of the original weight in the c-Kit ${ }^{-} \mathrm{ASCs}+4 \mathrm{~T} 1 / \mathrm{EPCs}$ group (19.14 g versus $19.65 \mathrm{~g}$, Figure 3(c)). However, there was no significant difference of the weight in each group $(p>0.05$, Figure $3(c))$.

3.4. $\mathrm{c}-\mathrm{Kit}^{+}$ASCs Promote EPC-Mediated Tumor Angiogenesis. Tumor angiogenesis is crucial to tumor growth. However, the role of ASCs in tumor angiogenesis is unclear. To explore the role for $\mathrm{c}-\mathrm{Kit}^{+} \mathrm{ASCs}$ in tumor angiogenesis, tumor grafts were analyzed by $\mathrm{H} \& \mathrm{E}$ staining and mouse-specific antiCD31 staining. Oil red $\mathrm{O}$ staining showed lots of mature adipose cells in the tumor tissues of the ASCs + 4T1/EPCs group (Figure $3(\mathrm{~d})$ ); however, H\&E and CD-31 immunostaining of tissue sections revealed broad vascularization in the $\mathrm{c}-\mathrm{Kit}^{+} \mathrm{ASC}+4 \mathrm{~T} 1 / \mathrm{EPC}$ group, in contrast to the other groups (Figure 3(e)). Quantification analysis revealed that the microvascular density was significantly higher in the coinjection groups containing c- $\mathrm{Kit}^{+}$ASCs than in the other injection groups $\left(81.3 \pm 3.1\right.$ vessels $/ \mathrm{mm}^{2}$ versus $65.0 \pm 10.0$ vessels $/ \mathrm{mm}^{2}$ in the $\mathrm{c}-\mathrm{Kit}^{-} \mathrm{ASC}+4 \mathrm{T1} / \mathrm{EPC}$ group, $p<0.05$; $37.3 \pm 4.2$ vessels $/ \mathrm{mm}^{2}$ in the EPCs/4T1 group, $p<0.001 ; 23.7$ \pm 5.1 vessels $/ \mathrm{mm}^{2}$ in the $4 \mathrm{~T} 1$ group, $p<0.001$, Figure $3(\mathrm{f})$ ), suggesting that $\mathrm{c}-\mathrm{Kit}^{+}$ASCs may enhance EPC-mediated tumor angiogenesis of breast cancer.

3.5. ${\mathrm{c}-\mathrm{Kit}^{+}}^{+}$ASCs Stimulate the Release of Interleukin-3 (IL3), Stromal Cell-Derived Factor-1 (SDF-1), and VEGF-A. ASCs produce several cytokines and chemokines that affect other surrounding cells, especially EPCs, thereby increasing tumor angiogenesis. To explore the molecular mechanisms by which $\mathrm{c}-\mathrm{Kit}^{+}$ASCs enhance EPC-mediated tumor angiogenesis of breast cancer, we analyzed the relevant cytokines, chemokines, and angiogenic growth factors. In direct coculture models, ELISA analyses revealed that the release of IL-3 significantly increased in the c-Kit ${ }^{+} \mathrm{ASC} / 4 \mathrm{~T} 1$ group in comparison to the c- $\mathrm{Kit}^{-} \mathrm{ASCs} / 4 \mathrm{~T} 1$ group $(1416.7 \pm 728.6 \mathrm{pg} / \mathrm{mL}$ versus $633.3 \pm 208.2 \mathrm{pg} / \mathrm{mL}, p<0.05$, Figure $4(\mathrm{a}))$ and the single culture groups $(483.3 \pm 175.6 \mathrm{pg} / \mathrm{mL}$ in the $4 \mathrm{~T} 1$ group, $p<0.05 ; 443.3 \pm 172.1 \mathrm{pg} / \mathrm{mL}$ in the $\mathrm{c}-\mathrm{Kit}^{-} \mathrm{ASC}$ group, $p<$ $0.05 ; 560.0 \pm 182.5 \mathrm{pg} / \mathrm{mL}$ in the $\mathrm{c}-\mathrm{Kit}^{+} \mathrm{ASC}$ group, $p<0.05$; Figure 4(a)). However, there was no significant difference in the SDF-1 $(p>0.05$, Figure 4(b)) and VEGF-A $(p>0.05$, Figure 4(c)) levels among the groups. 
IL-3

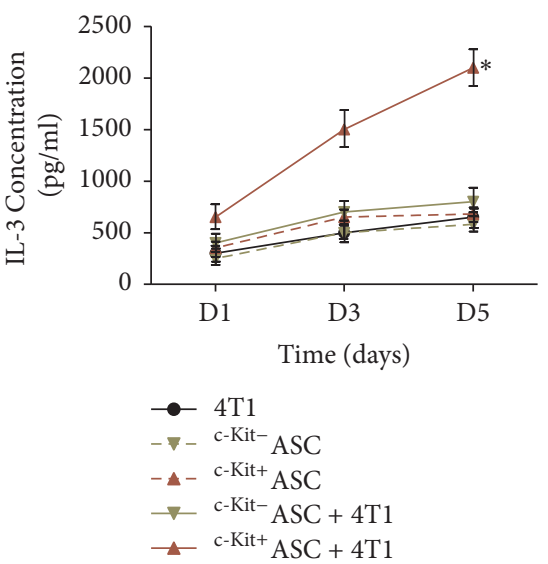

(a)

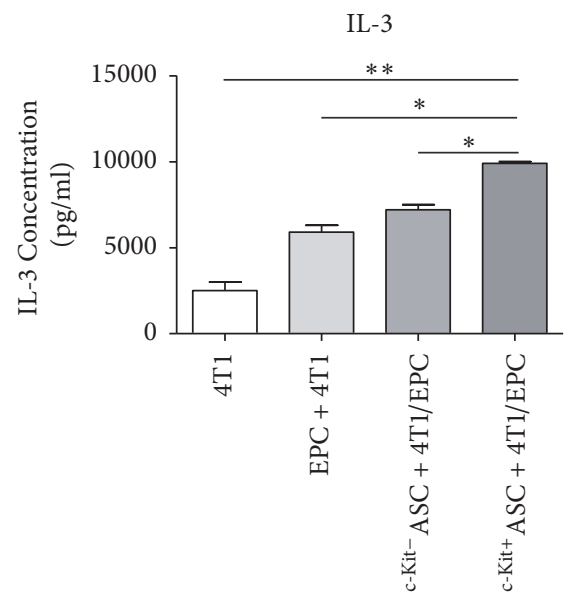

(d)
SDF-1

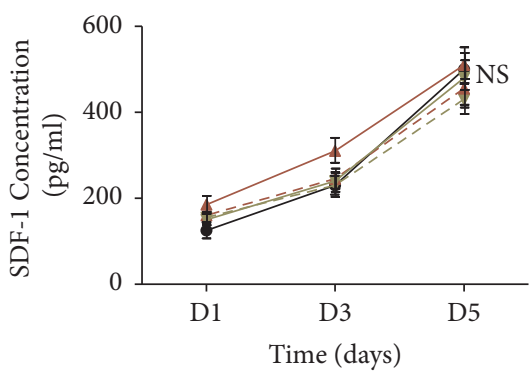

$\rightarrow 4 \mathrm{~T} 1$

- $-{ }^{c}$-Kit- ASC

$-{ }^{-{ }^{c-K i t+}} \mathrm{ASC}$

$\rightarrow{ }^{c-K i t-} \mathrm{ASC}+4 \mathrm{~T} 1$

$\simeq{ }^{\mathrm{c}-\mathrm{Kit}+} \mathrm{ASC}+4 \mathrm{~T} 1$

(b)

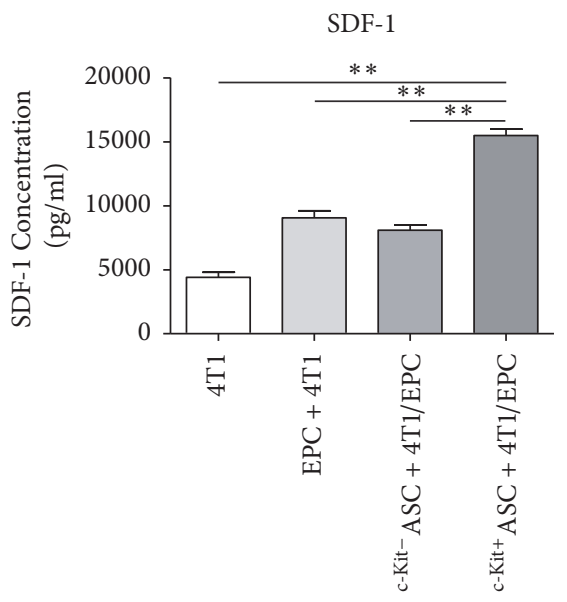

(e)
VEGFA

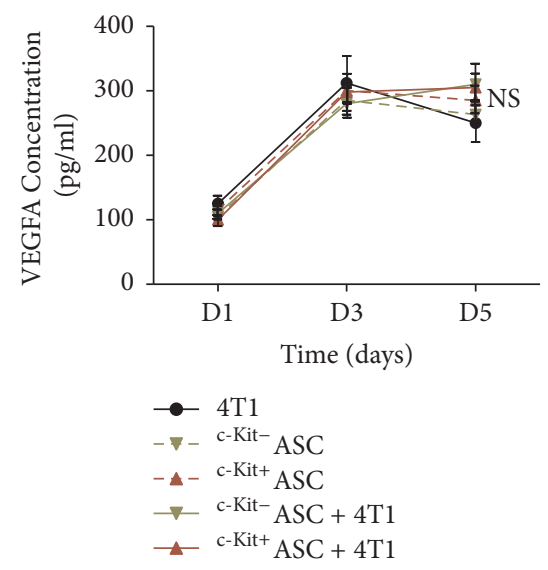

(c)

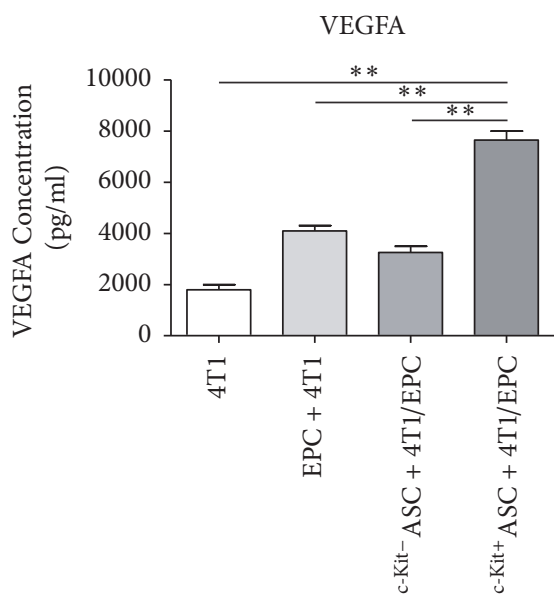

(f)

FIGURE 4: The release of cytokines and chemokines in c-Kit ${ }^{+}$ASCs. Cell culture supernatant and tumor tissue supernatant were collected and assayed with ELISA. ((a)-(c)) The release of IL-3 was significantly higher in the c-Kit ${ }^{+}$ASCs/4T1 direct coculture group in comparison with single culture; in contrast, there was a significant difference between the SDF-1 and VEGF-A levels among the groups. ((d)-(e)) The release of IL-3 as well as SDF-1 and VEGF-A was significantly increased in the coinjection group of EPCs/4T1 with c-Kit ${ }^{+}$ASCs, compared with the other groups. ${ }^{*} p<0.05 ;{ }^{* *} p<0.01$.

To extend our observation in vitro to mouse models in vivo, the levels of IL-3, SDF-1, and VEGF-A were assessed in tumor tissues. Interestingly, we found that IL-3 was significantly increased in the c-Kit ${ }^{+}$ASCs $+4 \mathrm{~T} 1 / \mathrm{EPC}$ group, compared with the c-Kit ${ }^{-}$ASCs $+4 \mathrm{~T} 1 /$ EPCs group $(9900.0$ $\pm 141.4 \mathrm{pg} / \mathrm{mL}$ versus $7250.0 \pm 353.6 \mathrm{pg} / \mathrm{mL}, p<0.05$ Figure $4(\mathrm{~d}))$ and the other groups $(5900 \pm 565.7 \mathrm{pg} / \mathrm{mL}$ in the EPCs/4T1 group, $p<0.05 ; 2500 \pm 707.1 \mathrm{pg} / \mathrm{mL}$ in the $4 \mathrm{~T} 1$ group, $p<0.01$, Figure $4(\mathrm{~d}))$. Moreover, the release of SDF-1 significantly increased in the c-Kit ${ }^{+}$ASCs + 4T1/EPCs group in comparison with the $\mathrm{c}-\mathrm{Kit}^{-} \mathrm{ASCs}+4 \mathrm{T1} / \mathrm{EPCs}$ group $(15500.0 \pm 707.1 \mathrm{pg} / \mathrm{mL}$ versus $8150.0 \pm 495.0 \mathrm{pg} / \mathrm{mL}, p<0.01$, Figure $4(\mathrm{e}))$ and the other groups $(9050.0 \pm 777.8 \mathrm{pg} / \mathrm{mL}$ in EPCs $/ 4 \mathrm{~T} 1$ group, $p<0.01 ; 4400.0 \pm 565.7 \mathrm{pg} / \mathrm{mL}$ in the $4 \mathrm{~T} 1$ group, $p<0.01$, Figure $4(\mathrm{e}))$. In addition, the level of VEGF-A was significantly higher in the c-Kit ${ }^{+}$ASCs + 4T1/EPCs group than in the c-Kit ${ }^{-} \mathrm{ASCs}+4 \mathrm{T1} / \mathrm{EPCs}$ group $(7650.0 \pm 495.0 \mathrm{pg} / \mathrm{mL}$ versus $3250.0 \pm 353.6 \mathrm{pg} / \mathrm{mL}, p<0.01$,
Figure 4(f)) and the other groups $(4150.0 \pm 212.1 \mathrm{pg} / \mathrm{mL}$ in EPCs $/ 4 \mathrm{~T} 1$ group, $p<0.01 ; 1800.0 \pm 282.8 \mathrm{pg} / \mathrm{mL}$ in the $4 \mathrm{~T} 1$ group, $p<0.01$, Figure 4(f)). However, there were no significant differences between the c-Kit ${ }^{-}$ASCs +4 T1/EPCs group and the EPCs/4T1 group in terms of the IL-3, SDF-1, and VEGF-A levels $(p>0.05$, Figures $4(\mathrm{~d})-4(\mathrm{f}))$.

\section{Discussion}

ASCs have been proposed to promote the viability of fat grafts and the efficacy of the procedure after breast cancer surgery $[23,24]$. However, emerging evidence indicates that ASCs may contribute to the growth and metastasis of breast cancer $[25,26]$. Conversely, other studies have demonstrated an inhibitory role of ASCs in breast cancer [6,7]. The contradiction warrants the selection of immunophenotypic markers of ASCs in clinical application. Our results demonstrated that $\mathrm{c}-\mathrm{Kit}^{+}$cells with characteristics of adipogenesis could be 
isolated from ASCs and that the $\mathrm{c}-\mathrm{Kit}^{+}$subpopulation was very rare, which is consistent with published observations that most stromal vascular fraction cells are c-Kit ${ }^{-}$[27-29].

There are distinct expression levels of c-Kit in stem cells/progenitor cells, melanocytes, and mast cells [30]. The c-Kit signaling network supports the proliferation, differentiation, and survival of c-Kit-expressing cells [31, 32]. In BRCA1 mutation-associated breast cancers, $\mathrm{c}-\mathrm{Kit}$ is required for the growth and survival of the tumor cells, and c-Kit activity may be downregulated to allow normal differentiation in adult tissue [33]. At present, to the best of our knowledge, no studies have shown the effect of $\mathrm{c}-\mathrm{Kit}^{+}$ASCs on breast cancer progression compared with the other subpopulations of ASCs. In the present study, we showed that the expression of $\mathrm{c}$-Kit increased in the $\mathrm{c}-\mathrm{Kit}^{+} \mathrm{ASCs} / 4 \mathrm{~T} 1$ coculture group compared with single cultures and that the proliferation of breast cancer cells was enhanced by $\mathrm{c}-\mathrm{Kit}^{+}$ASCs after coculture. Moreover, the release of membrane-bound KitL, as an adhesion/survival-promoting molecule for stem cells, depends on IL-3 [34]. IL-3 acts as a nonspecific proinflammatory cytokine and drives cell proliferation by the JAK/STAT and PI3K/AKT pathways [35-37]. Our results demonstrated that $\mathrm{c}-\mathrm{Kit}^{+}$ASCs stimulated IL-3 release both in vitro and in vivo. Taken together, our results suggest that c-Kit may stimulate the proliferation of $4 \mathrm{~T} 1$ breast cancer cells by promoting IL-3 release.

Tumor angiogenesis is crucial to tumor growth [38-40]. However, we found that the ASCs had no tube formation ability in vitro, and no palpable tumor masses formed in the ASCs injection alone group in mice. A previous study has shown the perivascular properties of ASCs in stabilizing these neovessels and the effect on EPC/endothelial cells by paracrine signaling in vivo [41]; accordingly, we implanted ASCs together with the EPCs that were isolated and cultured in the same conditions in order to eliminate their effect. Interestingly, we observed that $\mathrm{c}-\mathrm{Kit}^{+} \mathrm{ASC}$ significantly promoted tumor growth in combination with EPCs, compared to the $\mathrm{c}-\mathrm{Kit}^{-} \mathrm{ASC}$ coinjection group and the other groups, especially at 1 week after injection. Tumor angiogenesis is sustained by complicated cytokine networks among tumor cells and other cells in the tumor microenvironment [42-45]. We found that $\mathrm{c}-\mathrm{Kit}^{+}$ASCs had an intrinsic proangiogenic capability and stimulated IL-3 release, which could promote the proliferation of $4 \mathrm{~T} 1$ breast cancer cells or the growth of mature adipose cells. However, the tumor microenvironment in solid tumors is hypoxic, and c-Kit has been reported to participate in the formation of the tumor vasculature via promoting HIF- $1 \alpha$-mediated VEGF expression $[46,47]$. Boesiger et al. have shown that, in response to c-Kit/KitL, mouse or human mast cells rapidly release VEGF by degranulation and then sustain the release by secreting newly synthesized proteins [48]. Meanwhile, an increase of angiogenic factors, such as HIF-1 $\alpha$, SDF-1, and VEGF, in turn causes activation of matrix metalloproteinase- 9 and thus initiates recruitment and mobilization of BM-EPCs in the peripheral circulation [49]. Our results indicate that active $\mathrm{c}-\mathrm{Kit}^{+} \mathrm{ASC}$ may recruit myeloid cells by SDF-1 for angiogenesis, thereby stimulating EPCs to form vessels followed by the release of VEGF-A, which are crucial factors for the proliferation of breast cancer cells in the tumor microenvironment $[50,51]$.

Accumulating evidence suggests that ASCs may favor tumor progression by autocrine and paracrine signaling in different transplanted and metastatic tumor models. However, the interaction mechanism between ASCs and breast cancer in the tumor microenvironment remains to be determined. One limitation of our current study is the lack of continuous observation and cell tracking to discriminate different cell types and illuminate the specific role of cells in tumor angiogenesis in every group. Moreover, human tissue-derived $\mathrm{c}-\mathrm{Kit}^{+}$ASCs are needed to prove the function of $\mathrm{c}-\mathrm{Kit}^{+}$ASCs in breast cancer progression. In addition, multicenter clinical outcomes based on an adequate followup of breast cancer patients with an autologous fat graft are needed to compare $\mathrm{c}-\mathrm{Kit}^{+}$ASCs with other subpopulations of ASCs.

In conclusion, $\mathrm{c}^{-} \mathrm{Kit}^{+}$ASCs can promote the tumor angiogenesis and growth of breast cancer by recruiting EPCs via a synergistic effect of c-Kit and IL-3. Our findings suggest that identification of different phenotypes of ASCs may be required in reconstructive efforts with stem cell-enhanced fat grafting. Furthermore, c-Kit ${ }^{+}$ASCs should be avoided for use in breast reconstruction.

\section{Conflicts of Interest}

The authors declare that they have no conflicts of interest.

\section{Acknowledgments}

This work was supported by the Doctorial Innovation Fund of Harbin Medical University.

\section{References}

[1] J. M. Gimble, A. J. Katz, and B. A. Bunnell, "Adipose-derived stem cells for regenerative medicine," Circulation Research, vol. 100, no. 9, pp. 1249-1260, 2007.

[2] B. G. Rowan, J. M. Gimble, M. Sheng et al., "Human adipose tissue-derived stromal/stem cells promote migration and early metastasis of triple negative breast cancer xenografts," PLoS ONE, vol. 9, no. 2, Article ID e89595, 2014.

[3] P. Kamat, R. Schweizer, P. Kaenel et al., "Human adiposederived mesenchymal stromal cells may promote breast cancer progression and metastatic spread," Plastic and Reconstructive Surgery, vol. 136, no. 1, pp. 76-84, 2015.

[4] L. Kucerova, S. Skolekova, M. Matuskova, M. Bohac, and Z. Kozovska, "Altered features and increased chemosensitivity of human breast cancer cells mediated by adipose tissue-derived mesenchymal stromal cells," BMC Cancer, vol. 13, article 535, 2013.

[5] R. Pérez-Cano, J. J. Vranckx, J. M. Lasso et al., "Prospective trial of adipose-derived regenerative cell (ADRC)-enriched fat grafting for partial mastectomy defects: The RESTORE-2 trial," European Journal of Surgical Oncology, vol. 38, no. 5, pp. 382389, 2012.

[6] B. Sun, K.-H. Roh, J.-R. Park et al., "Therapeutic potential of mesenchymal stromal cells in a mouse breast cancer metastasis model," Cytotherapy, vol. 11, no. 3, pp. 289-298, 2009. 
[7] C. Senst, T. Nazari-Shafti, S. Kruger et al., "Prospective dual role of mesenchymal stem cells in breast tumor microenvironment," Breast Cancer Research and Treatment, vol. 137, no. 1, pp. 69-79, 2013.

[8] Y. Yarden, W. J. Kuang, T. Yang-Feng et al., "Human protooncogene c-kit: a new cell surface receptor tyrosine kinase for an unidentified ligand," EMBO Journal, vol. 6, no. 11, pp. 33413351, 1987.

[9] F. H. Qiu, P. Ray, K. Brown et al., "Primary structure of ckit: relationship with the CSF-1/PDGF receptor kinase familyoncogenic activation of $\mathrm{v}$-kit involves deletion of extracellular domain and C terminus," EMBO Journal, vol. 7, no. 4, pp. $1003-$ 1011, 1988 .

[10] F. Kuonen, J. Laurent, C. Secondini et al., "Inhibition of the kit ligand/c-kit axis attenuates metastasis in a mouse model mimicking local breast cancer relapse after radiotherapy," Clinical Cancer Research, vol. 18, no. 16, pp. 4365-4374, 2012.

[11] S. K. Kanapathy Pillai, A. Tay, S. Nair, and C.-O. Leong, "Triplenegative breast cancer is associated with EGFR, CK5/6 and cKIT expression in Malaysian women," BMC Clinical Pathology, vol. 12, article 18, 2012.

[12] A. Blazquez-Martinez, M. Chiesa, F. Arnalich, J. FernandezDelgado, M. Nistal, and M. P. De Miguel, "C-Kit identifies a subpopulation of mesenchymal stem cells in adipose tissue with higher telomerase expression and differentiation potential," Differentiation, vol. 87, no. 3-4, pp. 147-160, 2014.

[13] E. Resca, M. Zavatti, T. Maraldi et al., "Enrichment in cKit improved differentiation potential of amniotic membrane progenitor/stem cells," Placenta, vol. 36, no. 1, pp. 18-26, 2015.

[14] P. Nyberg, T. Salo, and R. Kalluri, “Tumor microenvironment and angiogenesis," Frontiers in Bioscience, vol. 13, no. 17, pp. 6537-6553, 2008.

[15] H. Korkaya, S. Liu, and M. S. Wicha, "Breast cancer stem cells, cytokine networks, and the tumor microenvironment," Journal of Clinical Investigation, vol. 121, no. 10, pp. 3804-3809, 2011.

[16] M. Moschetta, Y. Mishima, I. Sahin et al., "Role of endothelial progenitor cells in cancer progression," Biochimica et Biophysica Acta-Reviews on Cancer, vol. 1846, no. 1, pp. 26-39, 2014.

[17] A. Aguirre, J. A. Planell, and E. Engel, "Dynamics of bone marrow-derived endothelial progenitor cell/mesenchymal stem cell interaction in co-culture and its implications in angiogenesis," Biochemical and Biophysical Research Communications, vol. 400, no. 2, pp. 284-291, 2010.

[18] M. Ammendola, C. Leporini, M. Luposella et al., "Targeting endothelial progenitor cells in cancer as a novel biomarker and anti-angiogenic therapy," Current Stem Cell Research and Therapy, vol. 10, no. 2, pp. 181-187, 2015.

[19] K. E. Freese, L. Kokai, R. P. Edwards et al., "Adipose-derived stems cells and their role in human cancer development, growth, progression, and metastasis: A systematic review," Cancer Research, vol. 75, no. 7, pp. 1161-1168, 2015.

[20] R. Schweizer, P. Kamat, D. Schweizer et al., "Bone marrowderived mesenchymal stromal cells improve vascular regeneration and reduce leukocyte-endothelium activation in critical ischemic murine skin in a dose-dependent manner," Cytotherapy, vol. 16, no. 10, pp. 1345-1360, 2014.

[21] K. Akimoto, K. Kimura, M. Nagano et al., "Umbilical cord blood-derived mesenchymal stem cells inhibit, but adipose tissue-derived mesenchymal stem cells promote, glioblastoma multiforme proliferation," Stem Cells and Development, vol. 22, no. 9, pp. 1370-1386, 2013.
[22] A. H. Klopp, Y. Zhang, T. Solley et al., "Omental adipose tissuederived stromal cells promote vascularization and growth of endometrial tumors," Clinical Cancer Research, vol. 18, no. 3, pp. 771-782, 2012.

[23] S. K. Kapur, S. Dos-Anjos Vilaboa, R. Llull, and A. J. Katz, "Adipose tissue and stem/progenitor cells discovery and development," Clinics in Plastic Surgery, vol. 42, no. 2, pp. 155-167, 2015.

[24] D. M. Minteer, K. G. Marra, and J. P. Rubin, "Adipose stem cells: Biology, safety, regulation, and regenerative potential," Clinics in Plastic Surgery, vol. 42, no. 2, pp. 169-179, 2015.

[25] Q. Xu, L. Wang, H. Li et al., "Mesenchymal stem cells play a potential role in regulating the establishment and maintenance of epithelial-mesenchymal transition in MCF7 human breast cancer cells by paracrine and induced autocrine TGF- $\beta$," International Journal of Oncology, vol. 41, no. 3, pp. 959-968, 2012.

[26] R. Schweizer, W. Tsuji, V. S. Gorantla, K. G. Marra, J. P. Rubin, and J. A. Plock, "The role of adipose-derived stem cells in breast cancer progression and metastasis," Stem Cells International, vol. 2015, Article ID 120949, 2015.

[27] K. Cheng, A. Ibrahim, M. T. Hensley et al., "Relative Roles of CD90 and c-Kit to the Regenerative Efficacy of CardiosphereDerived Cells in Humans and in a Mouse Model of Myocardial Infarction," Journal of the American Heart Association, vol. 3, no. 5, Article ID e001260, 2014.

[28] J. Han, Y. J. Koh, H. R. Moon et al., "Adipose tissue is an extramedullary reservoir for functional hematopoietic stem and progenitor cells," Blood, vol. 115, no. 5, pp. 957-964, 2010.

[29] A. Zamperone, S. Pietronave, S. Merlin et al., "Isolation and characterization of a spontaneously immortalized multipotent mesenchymal cell line derived from mouse subcutaneous adipose tissue," Stem Cells and Development, vol. 22, no. 21, pp. 2873-2884, 2013.

[30] L. K. Ashman, "The biology of stem cell factor and its receptor C-kit," International Journal of Biochemistry and Cell Biology, vol. 31, no. 10, pp. 1037-1051, 1999.

[31] K. Nocka, J. Buck, E. Levi, and P. Besmer, "Candidate ligand for the c-kit transmembrane kinase receptor: $\mathrm{KL}$, a fibroblast derived growth factor stimulates mast cells and erythroid progenitors," EMBO Journal, vol. 9, no. 10, pp. 3287-3294, 1990.

[32] A. Yasuda, H. Sawai, H. Takahashi et al., “The stem cell factor/ckit receptor pathway enhances proliferation and invasion of pancreatic cancer cells," Molecular Cancer, vol. 5, article 46, 2006.

[33] J. L. Regan, H. Kendrick, F.-A. Magnay, V. Vafaizadeh, B. Groner, and M. J. Smalley, "C-Kit is required for growth and survival of the cells of origin of Brcal-mutation-associated breast cancer," Oncogene, vol. 31, no. 7, pp. 869-883, 2012.

[34] P. Dentelli, A. Rosso, C. Olgasi, G. Camussi, and M. F. Brizzi, "IL-3 is a novel target to interfere with tumor vasculature," Oncogene, vol. 30, no. 50, pp. 4930-4940, 2011.

[35] M. I. Mascarenhas, W. A. Bacon, C. Kapeni et al., "Analysis of Jak2 signaling reveals resistance of mouse embryonic hematopoietic stem cells to myeloproliferative disease mutation," Blood, vol. 127, no. 19, pp. 2298-2309, 2016.

[36] M. Schaller-Schönitz, D. Barzan, A. J. K. Williamson et al., "BCR-ABL affects STAT5A and STAT5B differentially," PLoS ONE, vol. 9, no. 5, Article ID e97243, 2014.

[37] SK. Kritas, A. Saggini, and G. Cerulli, "Interrelationship between IL-3 and mast cells," Journal of Biological Regulators and Homeostatic Agents, vol. 28, no. 1, pp. 17-21, 2014. 
[38] S. B. Fox, D. G. Generali, and A. L. Harris, "Breast tumour angiogenesis," Breast Cancer Research, vol. 9, no. 6, article 216, 2007.

[39] N. Weidner, J. P. Semple, W. R. Welch, and J. Folkman, “Tumor angiogenesis and metastasis-Correlation in invasive breast carcinoma," New England Journal of Medicine, vol. 324, no. 1, pp. 1-8, 1991.

[40] Z. Wang, C. Dabrosin, X. Yin et al., "Broad targeting of angiogenesis for cancer prevention and therapy," Seminars in Cancer Biology, vol. 35, pp. S224-S243, 2015.

[41] V. Haug, N. Torio-Padron, G. B. Stark, G. Finkenzeller, and S. Strassburg, "Comparison between endothelial progenitor cells and human umbilical vein endothelial cells on neovascularization in an adipogenesis mouse model," Microvascular Research, vol. 97, pp. 159-166, 2015.

[42] R. N. Gacche and R. J. Meshram, "Targeting tumor microenvironment for design and development ofnovel anti-angiogenic agents arresting tumor growth," Progress in Biophysics and Molecular Biology, vol. 113, no. 2, pp. 333-354, 2013.

[43] P. J. Sarvaiya, D. Guo, I. Ulasov, P. Gabikian, and M. S. Lesniak, "Chemokines in tumor progression and metastasis," Oncotarget, vol. 4, no. 12, pp. 2171-2185, 2013.

[44] M. Esquivel-Velázquez, P. Ostoa-Saloma, M. I. Palacios-Arreola, K. E. Nava-Castro, J. I. Castro, and J. Morales-Montor, "The role of cytokines in breast cancer development and progression," Journal of Interferon and Cytokine Research, vol. 35, no. 1, pp. 1-16, 2015.

[45] Z. Sun, S. Wang, and R. C. Zhao, "The roles of mesenchymal stem cells in tumor inflammatory microenvironment," Journal of Hematology and Oncology, vol. 7, no. 1, article 14, 2014.

[46] T. Zan, H. Li, Z. Du, B. Gu, K. Liu, and Q. Li, "Enhanced endothelial progenitor cell mobilization and function through direct manipulation of hypoxia inducible factor- $1 \alpha$," Cell Biochemistry and Function, vol. 33, no. 3, pp. 143-149, 2015.

[47] C. W. Pugh and P. J. Ratcliffe, "Regulation of angiogenesis by hypoxia: Role of the HIF system," Nature Medicine, vol. 9, no. 6, pp. 677-684, 2003.

[48] J. Boesiger, M. Tsai, M. Maurer et al., "Mast cells can secrete vascular permeability factor/vascular endothelial cell growth factor and exhibit enhanced release after immunoglobulin Edependent upregulation of Fce receptor I expression," Journal of Experimental Medicine, vol. 188, no. 6, pp. 1135-1145, 1998.

[49] D. Gao, D. J. Nolan, A. S. Mellick, K. Bambino, K. McDonnell, and V. Mittal, "Endothelial progenitor cells control the angiogenic switch in mouse lung metastasis," Science, vol. 319, no. 5860, pp. 195-198, 2008.

[50] F. Sato and M. Toi, "Molecular targeted therapy and genomic evolution of breast cancer," Nihon rinsho. Japanese journal of clinical medicine, vol. 73, no. 8, pp. 1364-1372, 2015.

[51] L. Kong, S. Guo, C. Liu et al., “Overexpression of SDF-1 activates the NF- $\kappa$ B pathway to induce epithelial to mesenchymal transition and cancer stem cell-like phenotypes of breast cancer cells," International Journal of Oncology, vol. 48, no. 3, pp. 1085-1094, 2016. 


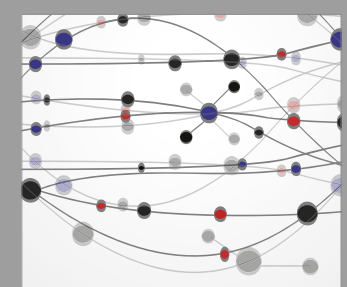

The Scientific World Journal
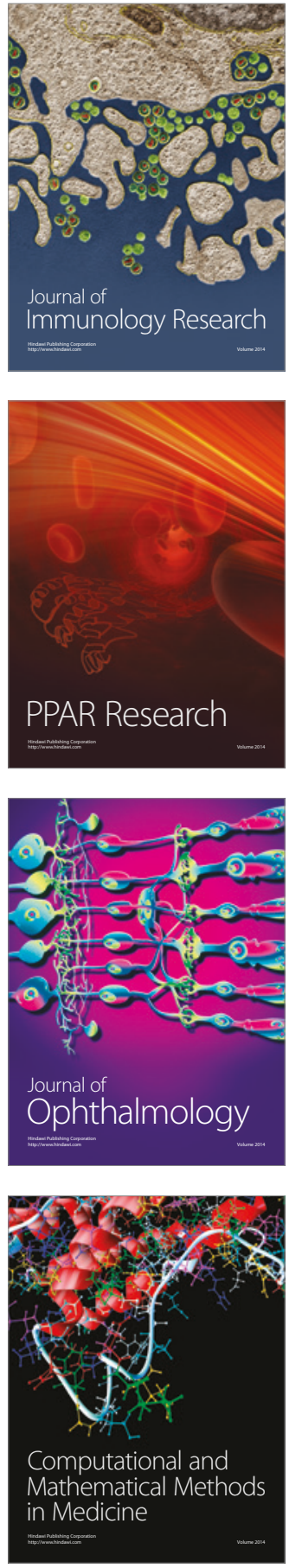

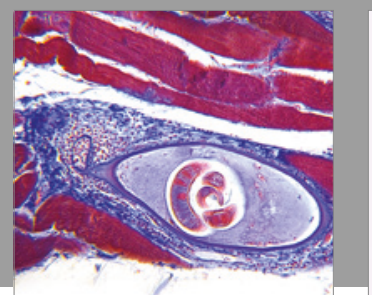

Gastroenterology Research and Practice
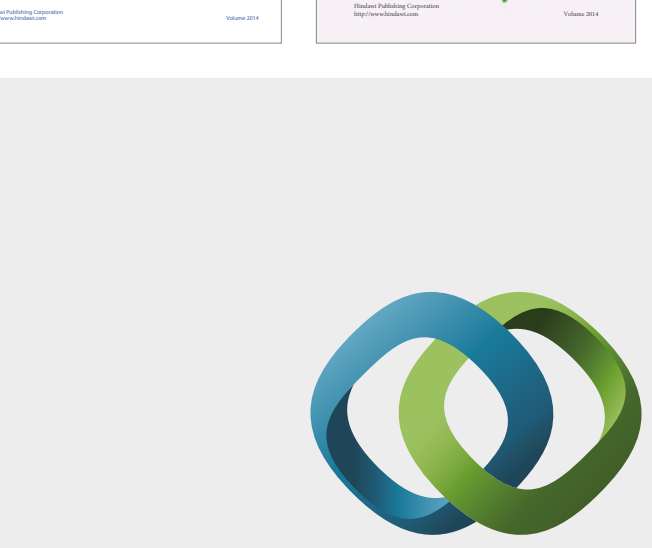

\section{Hindawi}

Submit your manuscripts at

https://www.hindawi.com
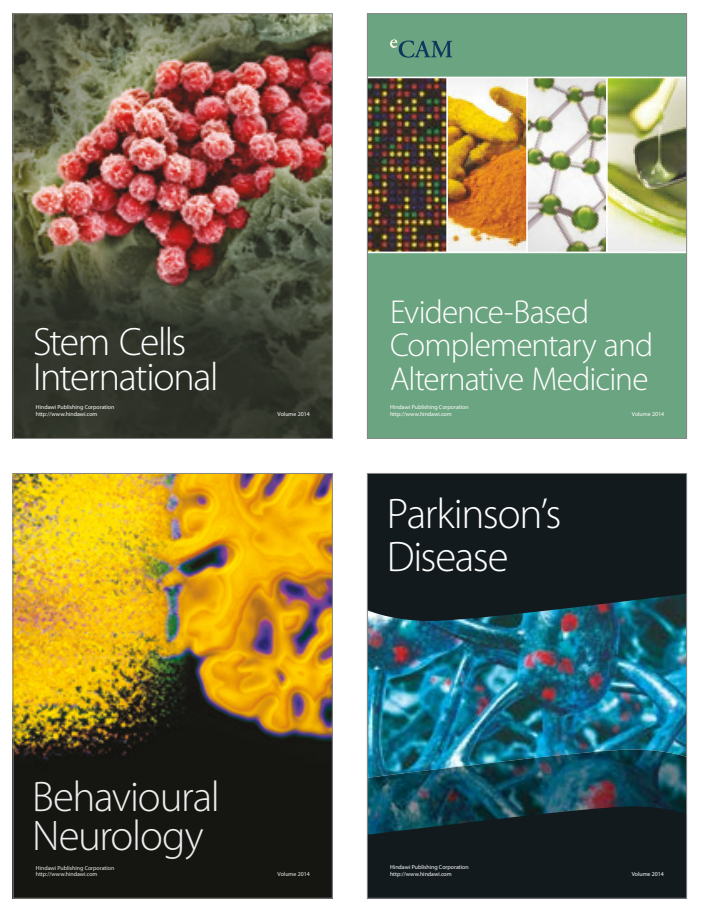
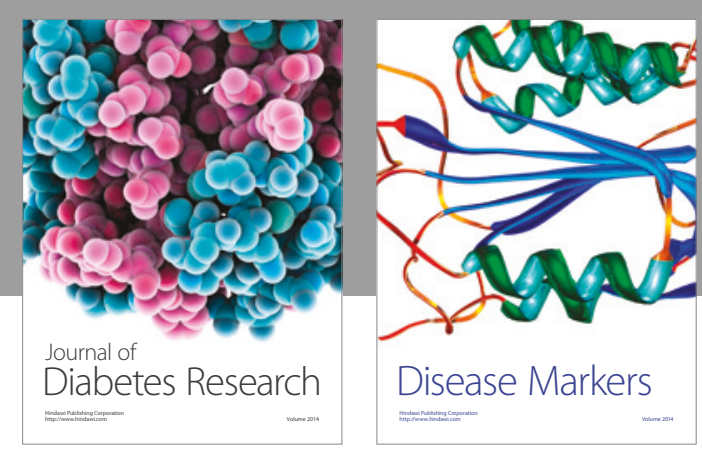

Disease Markers
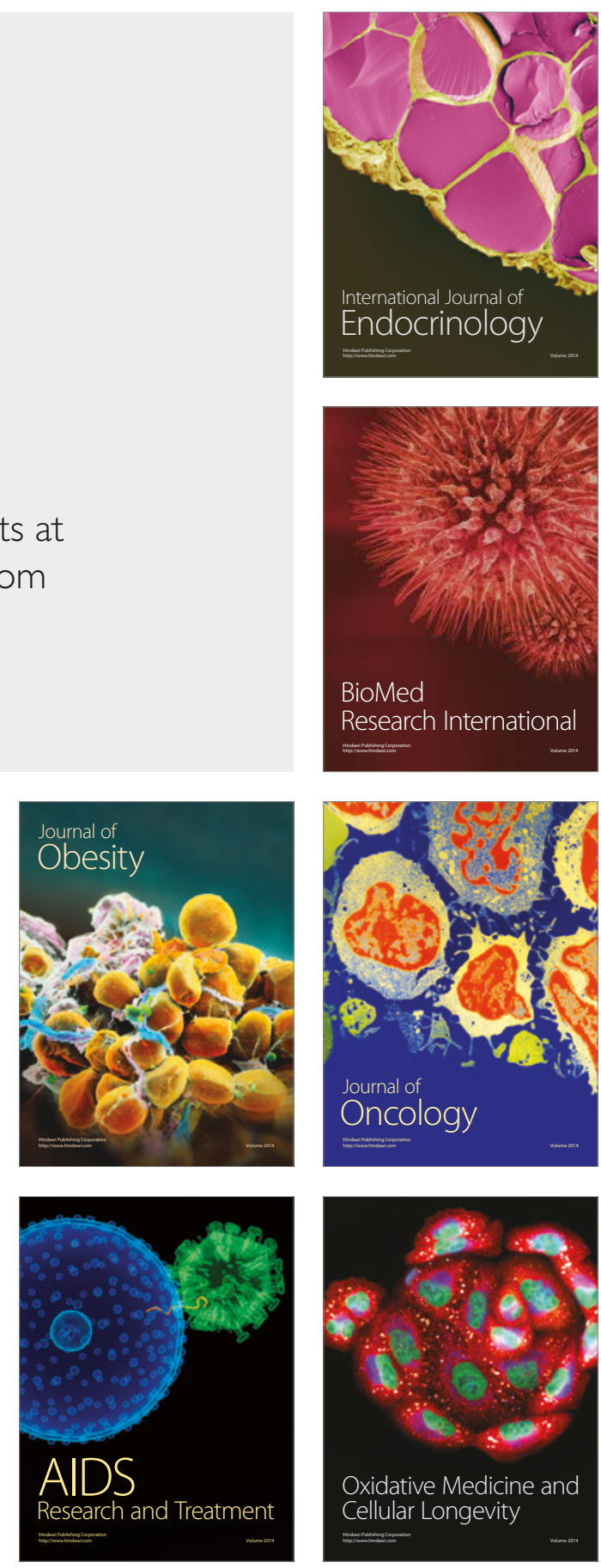